\title{
STRATEGI PEMASARAN ABON IKAN GABUS STUDI KASUS INDUSTRI RUMAH TANGGA KELOMPOK TAMPUNG PAREI PALANGKA RAYA
}

\author{
MARKETING STRATEGY ABON FISH GABUS \\ CASE STUDY OF HOUSEHOLD INDUSTRY TAMPUNG PAREI GROUP \\ PALANGKA RAYA
}

\author{
${ }^{1}$ Frisca Siburian, ${ }^{2}$ H. Ahmad Zaki Yamani, ${ }^{3}$ Revi Sunaryati \\ ${ }^{1}$ Alumnus Program Studi Agribisnis Fakultas Pertanian Universitas Palangka Raya \\ ${ }^{2,3}$ Staf Pengajar Program Studi Agribisnis Fakultas Pertanian Universitas Palangka Raya \\ email:ahmad.zaki@agb.upr.co.id
}

\begin{abstract}
ABSTRAK
Penelitian ini dilakukan untuk mengetahui bagaimana marketing mix yang digunakan di Kelompok Tampung Parei, untuk mengidentifikasi faktor internal dan eksternal yang menjadi kekuatan, kelemahan, peluang, ancaman dengan metode analisis IFAS dan EFAS dan untuk merumuskan alternatif strategi yang memungkinkan untuk diterapkan di Kelompok Tampung Parei dengan Matriks SWOT. Hasil penelitian ini menunjukkan bahwa: (1) Industri rumah tangga pengolahan abon ikan gabus Kelompok Tampung Parei sudah menjalankan strategi marketing mix, yaitu produk abon ikan gabus memiliki merek produk dengan nama "Laok Behau", harga jual produk abon ikan gabus yaitu sebesar Rp.50.000/100 gr, saluran distribusi yaitu saluran pemasaran langsung yaitu industri menerima pesanan abon ikan Gabus dari para konsumen, dan saluran tidak langsung, industri Kelompok Tampung Parei telah berkerjasama dengan beberapa agen penjual, Kegiatan promosi dilakukan dengan personal selling; (2) Kekuatan utama dalam industri rumah tangga Kelompok Tampung Parei berada pada variabel perizinan produk memberikan kepercayaan kepada konsumen dengan skor 0,68. Kelemahan utamanya berada pada variabel peralatan produksi yang sederhana dengan skor 0,48 . Peluang utama industri rumah tangga kelompok tamping parei berada pada variabel adanya perhatian pemerintah dan peluang pasar yang masih terbuka luas dengan skor 1,36. Selanjutnya ancaman utama berada pada variabel adanya persaingan usaha dengan skor 1,26; (3) Alternatif strategi yang dapat diterapkan pada industri rumah tangga kelompok tampung parei adalah strategi SO yaitu dengan memanfaatkan dukungan pemerintah dalam memperluas jaringan distribusi dan daerah pemasaran produk, mengingat peluang pasar yang masih terbuka dengan berkembangnya wisata di daerah Kalimantan Tengah, khususnya di Kota Palangka Raya dan memanfaatkan perkembangan teknologi dan informasi untuk pengembangan industri, melalui penggunaan alat teknologi dalam proses produksi yang dapat memberikan kemudahan dalam pengolahannya dan dapat mengurangi lama produksinya, penggunaan teknologi informasi yang tepat guna juga dapat membantu dalam kegiatan promosi.
\end{abstract}

Kata Kunci: Marketing mix, matriks SWOT, strategi pemasaran 


\begin{abstract}
This research is conducted to find out how marketing mix is used in Tampung Parei Group, to identify internal and external factors that become strength, weakness, threat possibility with IFAS and EFAS analysis method and to formulate possible strategy alternative to be applied in Tampung Parei Group with SWOT Matrix. The results of this study indicate that: (1) home industry abon processing gabus fish Tampung Parei Group has been running marketing mix strategy, that is product abon gabus fish brand product with name "Laok Behau", selling price abon gabus fish that is equal to Rp.50.000/100 gr, Distribution channel that is direct marketing channel that is industry accept order abon gabus fish from consumer, and indirect channel, industry Tampung Parei Group have cooperated with several agent of seller, Promotion activity done by personal selling; (2) The main strength in the household industry of Tampung Parei group is on the product licensing variable giving the consumer confidence with the score of 0.68. The main weakness is in the simple production equipment variables with a score of 0.48. The main opportunity of household industry of Tampung Parei Group is in the variable of government attention and market opportunity which is still wide open with score 1.36. While the main threat is in the variable of business competition with a score of 1.26; (3) The alternative strategy that can be applied to household industries of parei group is SO strategy that is by utilizing government support in expanding distribution network and product marketing area, considering the open market opportunity with tourism development in Central Kalimantan area, especially in the city of Palangka Raya and exploit the development of technology and information for industrial development, through the use of technology tools in the production process that can provide ease of processing and can reduce the length of its production, the use of appropriate information technology can also assist in promotional activities.
\end{abstract}

Keywords: Marketing mix, marketing strategy, SWOT matrix

\section{PENDAHULUAN}

Ikan sebagai komoditi utama di sub sektor perikanan merupakan salah satu bahan pangan yang kaya protein sehingga baik untuk dikonsumsi setiap harinya. Ikan merupakan komoditas yang mudah rusak dan cepat mengalami pembusukan. Seiring dengan berkembangnya teknologi, ikan dimanfaatkan sebagai bahan baku produk olahan. Produk olahan ini memiliki banyak variasi dan inovasi yang dapat meningkatkan nilai tambah dari komoditas perikanan. Berbagai keunggulan kegiatan pengolahan cukup mampu memberikan manfaat lebih terhadap komoditas perikanan, seperti daya tahan yang meningkat, penyimpanan yang mudah dan cita rasa serta keunikan ikan yang mampu merangsang tingkat konsumsi di masyarakat.

Salah satu produk olahan yang cukup terkenal dimasyarakat adalah abon ikan. Abon Ikan merupakan jenis olahan ikan yang diberi bumbu, diolah dengan cara perebusan dan penggorengan. Abon ikan biasanya digunakan sebagai makanan pendamping. Abon ikan baik digunakan oleh semua kalangan karena banyaknya gizi, terutama anak-anak yang masih dalam pertumbuhan dan baik bagi perkembangan otak karena mengandung protein tinggi, Omega 3, Omega 6 dan rendah kolesterol. Salah satu ikan yang dapat diolah menjadi abon ikan adalah ikan gabus.

Ikan gabus mempunyai nilai gizi yang tinggi dan baik untuk tubuh, namun para pengusaha industri pengolahan ikan gabus masih belum mengetahui bahwa 
keberhasilan kegiatan pemasaran pengolahan ikan gabus ini sangat ditentukan oleh strategi pemasaran yang dijalankannya. Pelaksanaan strategi yang tepat dan sesuai dalam pemasaran hasil industri akan membawa suatu usaha pada posisi persaingan yang semakin kuat. Dalam hal ini diperlukan adanya kebijakan manajerial yang tidak hanya mengelola aktivitas internal saja, melainkan juga harus menanggapi tantangan yang diakibatkan oleh faktor eksternal yang dinamis dan fleksibel. Adaptasi suatu usaha dengan faktor eksternal ini akan berdampak pada pembentukan strategi dalam menjalankan aktivitas usaha agar mampu bersaing.

Salah satu industri yang memproduksi abon ikan gabus adalah Industri Rumah Tangga Kelompok Tampung Parei. Abon ikan gabus merupakan produk terbaru yang ada di Industri Rumah Tangga Kelompok Tampung Parei dan memiliki volume penjualan yang masih rendah. Hal ini merupakan indikasi bahwa pemasaran yang dilakukan oleh industri rumah tangga ini belum optimal, sehingga sangat dibutuhkan strategi pemasaran yang tepat yang dapat membantu Industri Rumah Tangga Kelompok Tampung Parei dalam meningkatkan penjualan dan peningkatan keuntungan bagi pengusaha. Bauran pemasaran juga dibutuhkan untuk mengarahkan kegiatan pemasaran agar dapat lebih terarah dalam mencapai target pasar.

Penelitian ini bertujuan untuk mengetahui bauran pemasaran (marketing mix) yang digunakan di Industri Rumah Tangga Kelompok Tampung Parei, Faktor internal dan eksternal yang dihadapi oleh industri dan alternatif strategi yang dapat diterapkan dalam pemasaran produk olahan abon ikan gabus yang diproduksi oleh Industri Rumah Tangga Kelompok Tampung Parei.

\section{METODE PENELITIAN}

Metode yang digunakan dalam penelitian ini adalah metode studi kasus. Satuan kasusnya adalah usaha "Kelompok Tampung Parei". Studi kasus adalah penelitian tentang status penelitian yang berkenaan dengan suatu fase spesifik atau khas dari keseluruhan personalitas (Nazir 2000). Tujuannya yaitu memberikan gambaran secara terperinci mengenai latar belakang, sifat-sifat serta karakterkarakter yang jelas dari kasus ataupun status individu yang kemudian sifat-sifat khas tersebut dijadikan suatu hal yang bersifat umum.

Dalam penelitian ini data yang diperoleh diolah dalam bentuk tabulasi dan diedit ke dalam bentuk uraian penjelasan dari hasil wawancara. Dalam penelitian ini data yang digunakan adalah data kualitatif. Pengolahan data kualitatif dilakukan secara deskriptif yaitu dengan menguraikan data kualitatif yang diperoleh dari hasil wawancara di lokasi penelitian yang berhubungan dengan strategi pemasaran abon ikan gabus. Untuk melakukan analisa dari data-data yang diperoleh, digunakan alat analisis sebagai berikut:

1. Untuk mengetahui bauran pemasaran pada Industri Rumah Tangga Kelompok Tampung Parei digunakan analisis deskriptif. Analisis deskriptif yaitu metode analisis dengan cara mengumpulkan, mengolah, menyajikan dan menganalisis data sehingga diperoleh gambaran yang jelas mengenai masalah yang diteliti.

2. Untuk mengidentifikasi dan menganalisis faktor internal (kekuatan dan kelemahan) dan faktor eksternal (peluang dan ancaman) dalam penerapan suatu bauran pemasaran pada Industri Rumah Tangga Kelompok Tampung Parei digunakan analisis SWOT. Analisis SWOT yang digunakan untuk mengidentifikasi adalah dengan menentukan faktor kekuatan dan kelemahan, peluang dan ancaman pada industri rumah tangga 
Kelompok Tampug Parei, dan menganalisis faktor-faktor internal dan eksternal tersebut menggunakan Matriks IFAS dan EFAS.

3. Untuk merumuskan alternatif strategi yang akan diterapkan dalam pengembangan industri pengolahan abon ikan gabus di Kelompok Tampung Parei digunakan Analisis SWOT yaitu Matriks SWOT. Matriks SWOT dapat menggambarkan dengan jelas peluang dan ancaman dari faktor eksternal yang dihadapi oleh suatu usaha yang dapat disesuaikan dengan kekuatan dan kelemahan yang dimiliki.

\section{HASIL DAN PEMBAHASAN}

Industri Rumah Tangga pengolahan abon ikan gabus Kelompok Tampung Parei sudah menjalankan strategi marketing mix. Adapun komponen-komponen dalam startegi marketing mix tersebut adalah, sebagai berikut:

1. Produk. Produk olahan abon ikan gabus Kelompok Tampung Parei memiliki merek produk dengan nama "Laok Behau", adanya label yang berisi informasi produk seperti komposisi, tanggal kadaluarsa, logo halal, dan nomor dinas kesehatan.

2. Harga. Harga jual produk abon ikan gabus kelompok Tampung Parei yaitu sebesar Rp.50.000/kemasan/100gr. Kelompok Tampug Parei tidak memberikan harga diskon untuk setiap produk yang dipasarkan, tetapi memberi bonus kepada konsumen untuk pembelian dalam jumlah $10 \mathrm{pcs}$ mendapatkan bonus 1 pcs produk.

3. Distribusi. Saluran distribusi Kelompok Tampung Parei yaitu saluran pemasaran langsung yaitu industri melayani/menerima pesanan abon ikan gabus dari para konsumen, dan saluran tidak langsung, industri Kelompok Tampung Parei telah bekerjasama dengan beberapa agen penjual, diantaranya Toko Pusat Oleh-Oleh di
Jalan Batam, di Bandara Tjilik Riwut dan Toko Bonting di Jalan Ahmad Yani, Palangka Raya. Proses mendistribusikan produknya, industri menggunakan kendaraan motor.

4. Promosi. Kegiatan promosi yang dilakukan oleh kelompok Tampung Parei yaitu mempromosikan produknya dengan personal selling, dimana pengusaha akan menjelaskan secara lisan mengenai produknya dan menawarkan tester produk kepada konsumen. Pengusaha juga memperkenalkan produk olahannya dengan mengikuti pameran-pameran produk UMKM yang diselenggarakan oleh pemerintah setempat.

Berdasarkan analisis internal dan eskternal yang dilakukan terhadap Industri Rumah Tangga Kelompok Tampung Parei maka unsur-unsur yang termasuk dalam kekuatan. Kelemahan, peluang dan ancaman yang harus dihadapi dalam menghadapi persaingan, sebagai berikut:

Kekuatan

1. Lokasi usaha strategis

2. Pengalaman usaha dibidang kuliner

3. Saluran distribusi yang pendek

4. Kualitas produk yang baik

5. Legalitas Perizinan

6. Kemasan yang menarik

7. Tidak menggunakan pengawet

8. Sudah melakukan pengawasan dan evaluasi

Kelemahan

1. Rendahnya kualitas SDM anggota kelompok

2. Peralatan produksi sederhana

3. Distribusi produk belum luas

4. Belum efektifnya promosi

5. Sistem pembukuan masih sederhana

6. Tidak adanya keragaman produk

7. Harga yang kurang terjangkau

Peluang

1. Adanya perhatian pemerintah

2. Perkembangan teknologi dan informasi yang semakin maju

3. Peluang pasar masih luas

Ancaman 
1. Persaingan Usaha

2. Adanya fluktuasi harga bahan baku

Tabel 1. Tabel Matriks IFAS (Internal Strategi Factor Analysis Summary) Tabel Matriks EFAS (Eksternal Strategi Factor Analysis Summary)

\begin{tabular}{lccr}
\hline \multicolumn{1}{c}{ Faktor Strategis Internal } & Bobot & Rating & Bobot x Rating \\
\hline Kekuatan (Strength): & & & 0,12 \\
1. Lokasi Usaha Strategis & 3 & 0,36 \\
2. Pengalaman Usaha dibidang kuliner & 0,09 & 3 & 0,44 \\
3. Saluran distribusi yang pendek & 0,11 & 4 & 0,60 \\
4. Kualitas produk yang baik & 0,15 & 4 & 0,68 \\
5. Legalitas Perizinan & 0,17 & 4 & 0,56 \\
6. Kemasan yang menarik & 0,14 & 4 & 0,33 \\
7. Tidak menggunakan pengawet & 0,11 & 3 & 0,33 \\
8. Sudah melakukan pengawasan dan evaluasi & 0,11 & 3 &
\end{tabular}

\begin{tabular}{|c|c|c|c|}
\hline Jumlah & \multicolumn{2}{|c|}{1,00} & 3,57 \\
\hline \multicolumn{4}{|l|}{ Kelemahan (Weakness): } \\
\hline 1. Rendahnya kualitas SDM anggota kelompok & 0,15 & 2 & 0,30 \\
\hline 2. Peralatan produksi sederhana & 0,16 & 3 & 0,48 \\
\hline 3. Distribusi produk belum luas & 0,16 & 1 & 0,16 \\
\hline 4. Belum efektifnya promosi & 0,12 & 2 & 0,24 \\
\hline 5. Sistem pembukuan masih sederhana & 0,14 & 3 & 0,42 \\
\hline 6. Tidak adanya keragaman produk & 0,11 & 1 & 0,11 \\
\hline 7. Harga yang kurang terjangkau & 0,16 & 1 & 0,16 \\
\hline Jumlah & \multicolumn{2}{|l|}{1,00} & 1,87 \\
\hline \multicolumn{3}{|l|}{ Total Matriks IFAS } & \multirow[t]{2}{*}{5,44} \\
\hline Faktor Strategis Eksternal & Bobot & Rating & \\
\hline \multicolumn{4}{|l|}{ Peluang (Opportunity) } \\
\hline 1. Adanya perhatian pemerintah & 0,34 & 4 & 1,36 \\
\hline $\begin{array}{l}\text { 2. Perkembangan teknologi dan informasi yang } \\
\text { semakin maju }\end{array}$ & 0,32 & 3 & 0,96 \\
\hline 3. Peluang pasar masih luas & 0,34 & 4 & 1,36 \\
\hline Jumlah & \multicolumn{2}{|c|}{1,00} & 3,68 \\
\hline \multicolumn{4}{|l|}{ Ancaman (Treaths) } \\
\hline 1. Persaingan Usaha & 0,42 & 3 & 1,26 \\
\hline 2. Adanya fluktuasi harga bahan baku & 0,58 & 1 & 0,58 \\
\hline Jumlah & \multicolumn{2}{|c|}{1,00} & 1,84 \\
\hline Total Matriks EFAS & & & 5,52 \\
\hline
\end{tabular}

\section{Matriks SWOT}

Matriks SWOT menggambarkan secara jelas peluang dan ancaman eksternal dipadukan dengan kekuatan dan kelemahan internal, sehingga dihasilkan rumusan strategi pemasaran abon ikan gabus. Matriks ini menghasilkan empat sel kemungkinan alternatif strategi S-O, strategi W-O, strategi W-T, strategi S-T.
Berdasarkan analisis matriks SWOT, maka alternatif strategi yang diperoleh, sebagai berikut:

Strategi S-O

Strategi S-O (Strength-

Opportunity) atau strategi kekuatankekuatan peluang adalah strategi yang menggunakan kekuatan internal untuk memanfaatkan peluang eksternal. 
Alternatif strategi S-O yang dapat dirumuskan adalah:

1. Memanfaatkan dukungan pemerintah dalam memperluas jaringan distribusi dan daerah pemasaran produk. Strategi ini dilakukan untuk meningkatkan jumlah produk yang dipasarkan, mengingat peluang pasar yang masih terbuka dengan berkembangnya wisata di daerah Kalimantan Tengah, khususnya di Kota Palangka Raya. Pemerintah dapat membantu kegiatan pemasaran produk melalui kegiatan pameran yang diadakan, yang dapat membantu memperkenalkan produk olahan khas Palangka Raya dan tokotoko yang menjalin kerjasama juga dapat memperluas daerah pemasaran atau pendistribusian produk, sehingga dapat menambah pangsa pasar.

2. Memanfaatkan perkembangan teknologi dan informasi untuk pengembangan industri. Strategi ini dilakukan untuk meningkatkan kualitas dan kuantitas produk dengan memanfaatkan perkembangan teknologi dan informasi melalui penggunaan alat-alat teknologi dalam proses produksi yang dapat memberikan kemudahan dalam pengolahannya dan dapat mengurangi lama produksinya. Penggunaan teknologi informasi yang tepat guna juga dapat membantu dalam kegiatan promosi.

\section{Strategi W-O}

Strategi W-O

(WeaknessOpportunity) atau strategi kelemahanpeluang adalah strategi yang meminimalkan kelemahan yang ada untuk memanfaatkan peluang eksternal. Alternatif strategi W-O yang dapat dirumusan adalah:

1. Meningkatkan Kualitas SDM anggota kelompok dan memperbaiki sistem akuntansi melalui program pelatihan yang diadakan pemerintah setempat. Sumber Daya Manusia (SDM) adalah satu faktor penentu berhasil atau tidaknya suatu organisasi mencapai tujuannya. Meningkatkan kualitas SDM para anggota kelompok dan memperbaiki sistem akuntasi dapat dilakukan melalui mengikuti programprogram pelatihan yang diselenggarakan pemerintah juga pemilik usaha dapat membagikan pengetahuan dan keterampilannya kepada para anggota kelompoknya secara langsung.

2. Meningkatkan promosi dan mengoptimalkan volume produksi dengan memanfaatkan kemajuan teknologi dan informasi. Kegiatan promosi ini sesuatu yang sangat penting dalam upaya mengembangkan usaha. Dalam meningkatkan promosi dapat dilakukan dengan menyebarkan brosur dan memanfaatkan kemajuan teknologi dengan melakukan promosi melalui media internet. Optimalisasi volume produksi diperlukan untuk menghasilkan produk yang optimal. Optimalisasi dapat dilakukan dengan penggunaan teknologi yang tepat guna. Seperti telah disebutkan pada aspek teknologi, saat ini telah ada teknologi yang dapat diadaptasi untuk mendapatkan hasil produksi yang lebih optimal. Teknologi tersebut adalah sistem penggorengan secara mekanik yang berfungsi ganda sebagai penghancur dan pencampuran bumbu yang berguna untuk meningkatkan efisiensi kerja, kualitas abon dan pendapatan usaha.

3. Menciptakan produk dalam berbagai kemasan baru dalam berbagai rasa. Menciptakan produk dalam kemasan baru, seperti kemasan 20 g, 50 g, dan $100 \mathrm{~g}$, sehingga harga yang ditawarkan dipasaran beragam agar dapat terjangkau oleh kalangan masyarakat dan menciptakan produk dalam berbagai rasa sesuai dengan selera konsumen. 


\section{Strategi S-T}

Strategi S-T (Strenght-Threat) atau strategi kelemahan-ancaman adalah untuk mengoptimalkan kekuatan internal yang dimiliki dalam menghindari ancaman. Alternatif strategi S-T yang dapat dirumuskan adalah:

1. Mempertahankan kualitas dan manfaat produk dengan melakukan pengawasan dan evaluasi untuk menjaga kepercayaan konsumen dan toko yang bekerjasama, untuk dapat meningkatkan daya saing. Agar suatu produk mampu bersaing dengan produk pesaing, maka kualitas produk harus menjadi perhatian. Kualitas abon ikan gabus yang baik sangat tergantung dari proses pengolahannya. Abon ikan gabus harus diolah dengan baik agar tidak menghilangkan manfaat atau gizi dari ikan gabus yang baik untuk kesehatan. Pengusaha abon ikan gabus wajib untuk terus meningkatkan kualitas dari produk mereka untuk membuat pelanggan loyal/setia untuk mengkonsumsi produk kelompok Tampung Parei dan agar mampu meningkatkan daya saing sehingga tetap bertahan dalam usahanya dan mampu meningkatkan laba.

\section{Strategi W-T}

Strategi W-T (Weakness-Threat) atau strategi kelemahan-ancaman adalah strategi defensif untuk meminimalkan kelemahan internal dan menghindari ancaman eksternal untuk mengoptimalkan kekuatan internal yang dimiliki dalam menghindari ancaman. Alternatif strategi W-T yang dapat dirumuskan, adalah:

1. Meningkatkan kualitas sumber daya manusia dalam kemampuan manajemen. Kualitas sumberdaya manusia yang baik merupakan salah satu faktor penentu dalam perkembangan suatu usaha. Adanya keterampilan yang dimiliki oleh pekerja sebaiknya ditunjang oleh kualitas sumberdaya yang baik dalam bidang manajemen dan teknologi.
Kualitas sumber daya manusia perlu ditingkatkan agar pemilik maupun anggotanya memiliki pengetahuan dan keterampilan yang lebih baik, dapat memanfaatkan teknologi yang tepat guna dan mampu menerapkan sistem manajemen yang lebih baik di industrinya terlebih dalam pembukuan dan pencatatan transaksi keuangan.

Posisi Industri Rumah Tangga Kelompok Tampung Parei terletak pada kuadran satu (mendukung strategi agresif). Titik koordinat menempati posisi pada kuadran satu yaitu mendukung strategi agresif yang berarti situasi yang begitu menguntungkan. Industri Rumah Tangga Kelompok Tampung Parei memiliki peluang dan kekuatan sehingga dapat memanfaatkan peluang yang ada. Maka strategi yang dapat digunakan pada Industri Rumah Tangga Kelompok Tampung Parei tersebut yaitu mendukung strategi agresif ke arah kuadran I yaitu dengan lebih fokus kepada strategi SO (Strenghths-opportunities). Strategi S-O (Strength-Opportunity) atau strategi kekuatan-kekuatan peluang adalah strategi yang menggunakan kekuatan internal untuk memanfaatkan peluang eksternal. Alternatif strategi S-O yang dapat dirumuskan, adalah:

1. Memanfaatkan dukungan pemerintah dalam memperluas jaringan distribusi dan daerah pemasaran produk. Strategi ini dilakukan untuk meningkatkan jumlah produk yang dipasarkan, mengingat peluang pasar yang masih terbuka dengan berkembangnya wisata di daerah Kalimantan Tengah, khususnya di Kota Palangka Raya. Pemerintah dapat membantu kegiatan pemasaran produk melalui kegiatan pameran yang diadakan, yang dapat membantu memperkenalkan produk olahan khas Palangka Raya dan tokotoko yang menjalin kerjasama juga dapat memperluas daerah pemasaran atau pendistribusian produk, sehingga dapat menambah pangsa pasar. 
2. Memanfaatkan perkembangan teknologi dan informasi untuk pengembangan industri. Strategi ini dilakukan untuk meningkatkan kualitas dan kuantitas produk dengan memanfaatkan perkembangan teknologi dan informasi melalui penggunaan alat-alat teknologi dalam proses produksi yang dapat memberikan kemudahan dalam pengolahannya dan dapat mengurangi lama produksinya. Penggunaan teknologi informasi yang tepat guna juga dapat membantu dalam kegiatan promosi.

\section{KESIMPULAN DAN SARAN}

\section{Kesimpulan}

Berdasarkan hasil dan pembahasan yang telah dilakukan, maka dapat diambil kesimpulan sebagai berikut:

1. Industri Rumah Tangga Pengolahan Abon Ikan Gabus Kelompok Tampung Parei sudah menjalankan strategi marketing mix. Adapun komponenkomponen dalam startegi marketing mix tersebut adalah produk, harga, distribusi, dan promosi.

2. Hasil skoring yang didapat dari faktor internal dan eksternal dalam strategi pemasaran abon ikan gabus Industri Rumah Tangga Kelompok Tampung Parei yaitu berupa faktor kekuatan 3,57 dan kelemahan 1,87. Kemudian dikurangi dengan kriteria kekuatan dan kelemahan sehingga mendapatkan koordinatnya sebesar 1,70. Selanjutnya faktor peluang 3,68 dan ancaman 1,84. Kemudian dikurangi peluang dan ancaman sehingga mendapatkan koordinatnya sebesar 1,84. Dengan demikian posisinya berada di kuadran I (satu) dengan demikian industri rumah tangga kelompok Tampung Parei pada kuadran ini merupakan situasi yang menguntungkan. Memiliki peluang dan kekuatan dapat memanfaatkan peluang yang ada. perumusan ini menggunakan matriks SWOT yang didasarkan pada penggabungan faktor internal dan eksternal.

3. Alternatif strategi yang dapat diterapkan dalam pemasaran abon ikan gabus industri rumah tangga kelompok Tampung Parei adalah strategi S-O (Strength-Opportunity), yaitu dengan memanfaatkan dukungan pemerintah dalam memperluas jaringan distribusi dan daerah pemasaran produk, mengingat peluang pasar yang masih terbuka dengan berkembangnya wisata di daerah Kalimantan Tengah, khususnya di Kota Palangka Raya, dan memanfaatkan perkembangan teknologi dan informasi untuk pengembangan industri, melalui penggunaan alat-alat teknologi dalam proses produksi yang dapat memberikan kemudahan dalam pengolahannya dan dapat mengurangi lama produksinya dan penggunaan teknologi informasi yang tepat guna juga dapat membantu dalam kegiatan promosi.

\section{Saran}

Berdasarkan kesimpulan di atas, maka dapat disarankan:

1. Bagi pemilik usaha industri rumah tangga abon ikan gabus Kelompok Tampung Parei perlu senantiasa mempertahankan dan meningkatkan kualitas produknya, meningkatkan promosi, dan meningkatkan kualitas SDM dengan memanfaatkan perkembangan teknologi informasi dengan membuat web penjualan online, dan menciptakan produk dalam berbagai kemasan baru dan rasa baru, agar harga yang ditawarkan dipasaran beragam agar dapat terjangkau oleh kalangan masyarakat dan menciptakan produk dalam berbagai rasa yang sesuai dengan selera konsumen, agar dapat mengembangkan industri dan memperluas distribusi produk. 
2. Bagi Pemerintah Kota Palangka Raya agar dapat memberikan kebijakankebijakan yang mendukungan industri rumah tangga usaha pengolahan hasil perikanan terkait pengembangan usaha agar dapat memenuhi permintaan wisatawan terhadap produk lokal khas Palangka Raya.

\section{DAFTAR PUSTAKA}

Badan Pusat Statistika Kota Palangka Raya. (2016). Provinsi Kalimantan Tengah Dalam Angka 2015. Palangka Raya: Badan Pusat Statistik.

Bambang, Murtidjo. (2001). Beberapa Metode Pembenihan Ikan Air Tawar. Yogyakarta: Kanisius.

Bungin, B. (2003). Analisis Data Penelitian Kualitatif. Pemahaman Filisofis dan Metodologis ke arah Penguasaan Model Aplikasi. Jakarta: Raja Grafindo Persada.

Dinas Kelautan dan Perikanan Provinsi Kalimantan Tengah. (2016). Laporan Tahunan Statistik Perikanan Budidaya Kalimantan Tengah. Palangka Raya: Dinas Kelautan dan Perikanan Provinsi Kalimantan Tengah.

Dinas Perikanan Kota Palangka Raya. (2017). Laporan Tahunan Statistik Perikanan Budidaya Kota Palangka Raya Tahun 2013 s/d 2016. PalangkaRaya: Dinas Perikanan Kota Palangka Raya.

Fuad. (2008). Pengantar Bisnis, Edisi Keenam, Cetakan Ketiga belas. Jakarta: Gramedia PustakaUtama.

Ghufran, M. (2010). A to Z Budidaya Biota Akuatik untuk Pangan, Kosmetik dan Obat-obatan. Yogyakarta: Penerbit Andi.

Griffin. (2003). Bisnis Edisi Keenam. Jakarta: PT. Prenhallindo.

Ibrahim, B. (2004). Pendekatan Penerapan Produksi Bersih Pada Industri Pengolahan Hasil Perikanan.
Buletin Teknologi Hasil Perikanan Vol VII Nomor 1.

Kartajaya, H. (2004). Hermawan Kartajaya on Marketing. Jakarta: PT. Gramedia.

Kotler, Philip dan Kevin L. Keller. (2007). Manajemen Pemasaran Edisi 12 Jilid 2. Jakarta: Indeks.

Kotler, Philip. (2007). Manajemen Pemasaran Jilid I. Terjemahan. Jakarta: Indeks.

Rangkuti, Freddy. (2006). Analisis SWOT: Teknik Membedah Kasus Bisnis. Jakarta: Gramedia Pustaka Utama.

Siagian. (2000). Strategi Usaha. Jakarta: Gramedia Pustaka Utama.

Sudiyono, Armand. (2004). Pemasaran Pertanian. UMM, Malang.

Suprapti, L. (2008). Teknologi Pengolahan Pangan: Produk Olahan Ikan. Yogyakarta: Kanisius.

Swastha, Basu dan Irawan. (2003). Manajemen Pemasaran Modern. Yogyakarta: Liberty.

Tjiptono, F. (2010). Strategi Pemasaran. Yogyakarta: Andi Offset. 